\title{
Perancangan Pemanfaatan Pompa Air Tenaga Surya Untuk Sumber Air Bersih Desa Sukarame, Kec. Sajira, Banten
}

\author{
1, 2, 3,4 Institut Teknologi PLN \\ ${ }^{1}$ yoakim@itpln.ac.id \\ 2 titiratnasari@itpln.ac.id \\ ${ }^{3}$ agunghariyanto@itpln.ac.id \\ ${ }^{4}$ hakimulbatih@itpln.ac.id
}

Yoakim Simamora $^{1}$; Titi Ratnasari ${ }^{2}$; Agung Hariyanto ${ }^{3}$; Hakimul Batih ${ }^{4}$

\begin{abstract}
Water requirements for the people in sukarame village, Sajira, for daily needs in the dry season tend to increase, They always experience drought for 6-9 months annually. The people independently built water reservoirs from mountain water sources. Water is pumped using a water pumping machine and accommodated in reservoirs, then distributed to local residents through pipes with minimum distribution distance is $1 \mathrm{~km}$ from the reservoir. Because the distance between water sources and the people complaining about clean water does not reach their homes. This problem can be done by building a ground well located not far from the house of the community, so that the distance between the source of clean water and the house of the community is not too far, water from the water source will be accommodated in reservoirs by sucking ground water using a solar water pump so residents are not burdened with electricity fees to suck ground well water into clean air tendons. This design is expected to provide a solution for clean water sources for volunteers in the village of Sajira.
\end{abstract}

Keywords: Watersource, Solar panel, clean water, water pump driven solar panel

\begin{abstract}
ABSTRAK
Kebutuhan air bersih untuk masyarakat desa sukarame, kecamatan sajira, untuk kebutuhan seharihari pada musim kemarau cenderung meningkat, sementara desa tersebut selalu mengalami kekeringan selama 6-9 bulan setiap tahunnya. Hal ini menyebabkan Masyarakat desa sukarame secara swadaya membangun penampung air yang berasal dari sumber air gunung. Air dipompa menggunakan mesin pompa air dan ditampung di tandon untuk kemudian disalurkan ke warga sekitar melalui pipa dengan jarak penyaluran air paling dekat $1 \mathrm{~km}$ dari tandon ke rumah masyarakat menggunakan pompa listrik untuk memenuhi kebutuhan air bersih. Akibat jarak antar sumber air bersih dan mayoritas masyarakat mengeluhkan bahwa air bersih tidak sampai ke rumah mereka. Permasalahan ini dapat dilakukan dengan cara membangun sumur tanah yang lokasi nya tidak jauh dari rumah masyarakat, sehimgga jarak antara sumber air bersih dan rumah masyarakat tidak terlalu jauh, air dari sumur tanah akan di tampung di tandon dengan cara menghisap air tanah menggunakan pompa air tenaga surya sehingga warga tidak dibebani iuran listrik untuk menghisap air sumur tanah ke tendon air bersih. Perancangan ini diharapkan dapat memberi solusi sumber air bersih bagi masyarakat desa sukarame kecamatan sajira.
\end{abstract}

Kata kunci: Sumber Air, Energi Surya, Sumur Tanah, Pompa Air Tenaga Surya 


\section{PENDAHULUAN}

Air bersih merupakan salah satu kebutuhan manusia yang sangat vital. Oleh karena itu ketersediaan air bersih menjadi hal yang harus selalu diperhatikan karena menyangkut kebutuhan primer manusia. Negara Indonesia yang sebagian besar wilayahnya berupa perairan nyatanya masih mengalami kesulitan untuk memenuhi kebutuhan penduduknya dalam hal pemenuhan air bersih. Berdasarkan data dari Badan Pusat Statistik pada tahun 2018, persentase rumah tangga dengan sumber air minum bersih adalah 72,99\% (BPS, 2018)

Salah satu provinsi yang selalu mengalami permasalahan krisis air bersih setiap tahunnya adalah Provinsi Banten. Dengan penduduk pada tahun 2018 sejumlah 12.689.736 jiwa (data BPS Prov. Banten), Provinsi Banten kesulitan untuk memenuhi kebutuhan akan air bersih bagi penduduknya. Seperti yang terjadi di Kabupaten Lebak tahun ini, kemarau panjang menyebabkan Kabupaten Lebak dilanda kekeringan terparah sejak 1997. Nazmudin, 2019). Dari 28 kecamatan di Kabupaten Lebak, 16 diantaranya mengalami kekeringan dan kondisinya memprihatinkan karena kesulitan akses air bersih.

Kecamatan Sajira di Kabupaten Lebak merupakan kecamatan yang terdampak kekeringan dengan kondisi cukup parah. Berdasarkan pengakuan warga, Kecamatan Sajira selalu mengalami kekeringan selama 6-9 bulan setiap tahunnya. Warga terpaksa memenuhi kebutuhan air dari sungai setempat yang kadang tidak layak konsumsi karena di sungai tersebut juga dijadikan warga sebagai tempat MCK (mandi, cuci, kakus). Alternatif air untuk konsumsi diperoleh warga dari sumber air yang letakknya cukup jauh dari pemukiman. Bahkan saat ini sungai tersebut sudah sangat kering akibat kemarau Panjang.

Masyarakat Desa Sukarame secara swadaya membuat sumur di dekat gunung agar terdapat sumber air bersih. Air dipompa menggunakan mesin pompa air dan ditampung di tandon untuk kemudian disalurkan ke warga sekitar melalui pipa dengan jarak penyaluran air minimal $1 \mathrm{~km}$. Akibat minimnya mesin yang tersedia, serta tidak adanya tandon yang layak, banyak warga yang mengeluhkan jika air tidak dapat sampai ke rumah mereka. Hal tersebut juga diakibatkan minimnya sumber listrik untuk mesin air dalam pemenuhan air bersih bagi warga Desa Sukarame. Selama musim kemarau, semua warga mengandalkan sumber air tersebut, hingga persediaan tidak dapat mencukupi kebutuhan warga. Oleh karena itu, sistem sumber air bersih perlu adanya perbaikan, agar kebutuhan warga akan air bersih dapat terpenuhi seluruhnya.

Perbaikan dapat dilakukan dengan cara menambah mesin pompa air dan tandon di Sumur tersebut. Sehingga tandon akan terisi lebih banyak air dalam waktu yang cukup singkat karna ada dua mesin air untuk memenuhi kebutuhan air bersih. Agar pengoperasian mesin pompa air tidak membebani warga dengan biaya listrik, maka ditambahkan pula sistem panel surya sebagai catu daya bagi mesin pompa air.

Permasalahan yang terjadi berkaitan dengan minimya air bersih khususnya bagi warga Desa Sukarame, Kec. Sajira Kab. Lebak dapat diatasi dengan adanya pengabdian kepada masyarakat yang dilakukan oleh civitas akademika IT-PLN sebagai salah satu bentuk Tri Darma Perguruan Tinggi. Berbekal pengetahuan mengenai tenaga surya maka dapat dipasang mesin pompa air di tandon swadaya masyarakat yang mengambil sumber melalui sel surya (solar cell). Penggunaan sel surya selain menguntungkan warga karena warga tidak perlu terbebani dengan biaya listrik, juga dapat menjadi sarana edukasi bagi masyarakat sekitar mengenai implementasi energi baru dan terbarukan 


\section{METODOLOGI}

\subsection{Lokasi Kegiatan}

Program Kemitraan Masyarakat dengan tema "Perancangan Pemanfaatan Pompa Air Tenaga Surya Untuk Sumber Air Bersih Desa Sukarame" yang berlokasi di, Kec. Sajira, Lebak Banten. Secara geografis Desa Sukarame berada pada $-6,473268$ lintang utara dan 106,361714 Bujur Timur. Luas wilayah sekitar $300 \mathrm{~m}^{2}$.

\subsection{Survey dan Analisa Ketersediaan Air Bersih}

Kecamatan Sajira di Kabupaten Lebak merupakan kecamatan yang terdampak kekeringan dengan kondisi cukup parah. Berdasarkan pengakuan warga, Kecamatan Sajira selalu mengalami kekeringan selama 6-9 bulan setiap tahunnya. Akibat jauhnya sumber air bersih (sungai) dari pemukiman warga dan minimnya mesin yang tersedia, serta tidak adanya tandon yang layak, banyak warga yang mengeluhkan jika air tidak dapat sampai ke rumah mereka. Hal tersebut juga diakibatkan minimnya sumber listrik untuk mesin air dalam pemenuhan air bersih bagi warga Desa Sukarame.

Kegiatan survey ini dalam pelaksanaanya melibatkan tokoh masyarakat setempat dan mahasiswa sebagai anggota tim untuk membantu instalasi pemasangan panel dan instalasi penyaluran air bersih nantinya. Survey dilakukan sebanyak dua kali.

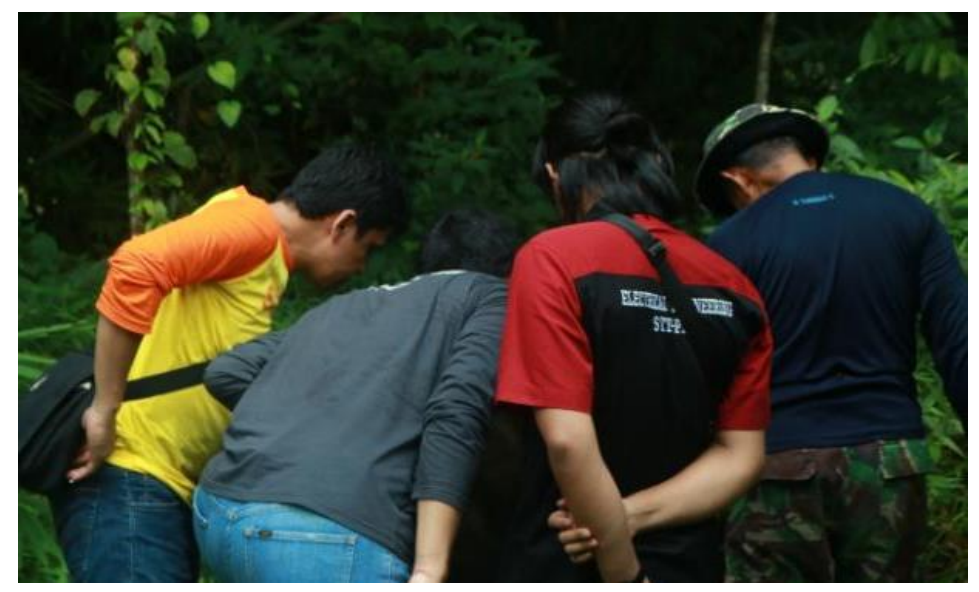

Gambar 1. Survey Lokasi

Survey dilakukan untuk menentukan letak sumur tanah yang akan dipasang pompa air tenaga surya dan tandon dan mengukur kedalaman sumur tanah debit air di lokasi tersebut, kontiniutas penyaluran air menjadi hal yang paling utama yang perlu diperhatikan, untuk memastikan itu maka dilakukan peninjauan dan pengukuran langsung ke sumber air yang ada serta dikuatkan dengan wawancara dengan warga setempat. Sumber air yang memungkinkan untuk disalurkan lokasi nya berada di sekitar perkebunan $1 \mathrm{~km}$ diatas pemukiman warga.

\subsection{Sifat dan Bentuk Kegiatan}

Program Kemitraan Masyarakat dengan tema "Perancangan Pemanfaatan Pompa Air Tenaga Surya Untuk Sumber Air Bersih Desa Sukarame, Kecamatan Sajira, Lebak, Banten dilaksanakan paling sedikit 2 kali survey ke lokasi yang dilakukan pada hari kerja yaitu dengan melihat lokasi sumber mata air dengan pertimbangan jarak antara sumber air yang akan dipasang pompa air tenaga surya dan rumah warga cukup terjangkau. Berdasarkan survei lapangan, dipilih tempat strategis yang terletak di areal perkebunan didekat perumahan warga, sumber air bersih (sumur tanah) tersebut 
memiliki kedalaman $15 \mathrm{~m}$..Secara garis besar, metode pelaksanaan kegiatan pengabdian masyarakat ini adalah sebagai berikut:

Tahap 1: Tim memulai komunikasi dengan tokoh masyarakat desa sukarame, untuk membicarakan tujuan program kemitraan masyarakat IT PLN

Tahap 2: Tim mengadakan peninjauan lokasi ke desa sukarame Kecamatan Sajira Kab. Lebak, Banten untuk menentukan lokasi sumber air bersih pemasangan pompa air Tenaga Surya untuk membantu menghisap air dari sumur tanah ke tandon air

Tahap 3: Tim menghitung dan menyiapkan beberapa peralatan diantaranya kapasitas pompa air, panel surya, kapasitas baterai, spesifikasi controller, toran air dan pipa penyaluran air yang dibutuhkan

Tahap 4: Tim mendesain wiring pompa air tenaga surya + controller + baterai + solar panel .

Tahap 5: Pengadaan alat untuk keperluan instalasi pompa air tenaga surya

Tahap 6: Tim bersama warga memasang pompa air tenaga surya dan atndon air di lokasi sumber air yang sudah ditentukan

Tahap 7: Tim bersama warga mengada diskusi terbuka terkait prinsip kerja pompa air tenaga surya, dan perawatan pompa tenaga surya agar bisa berthana lama

Tahap 8: Tim mengadakan evaluasi kegatan serta persiapan penyusunan laporan akhir kegiatan

\subsection{Diagram Alir Kegiatan}

Metode yang digunakan dalam kegiatan ini adalah:

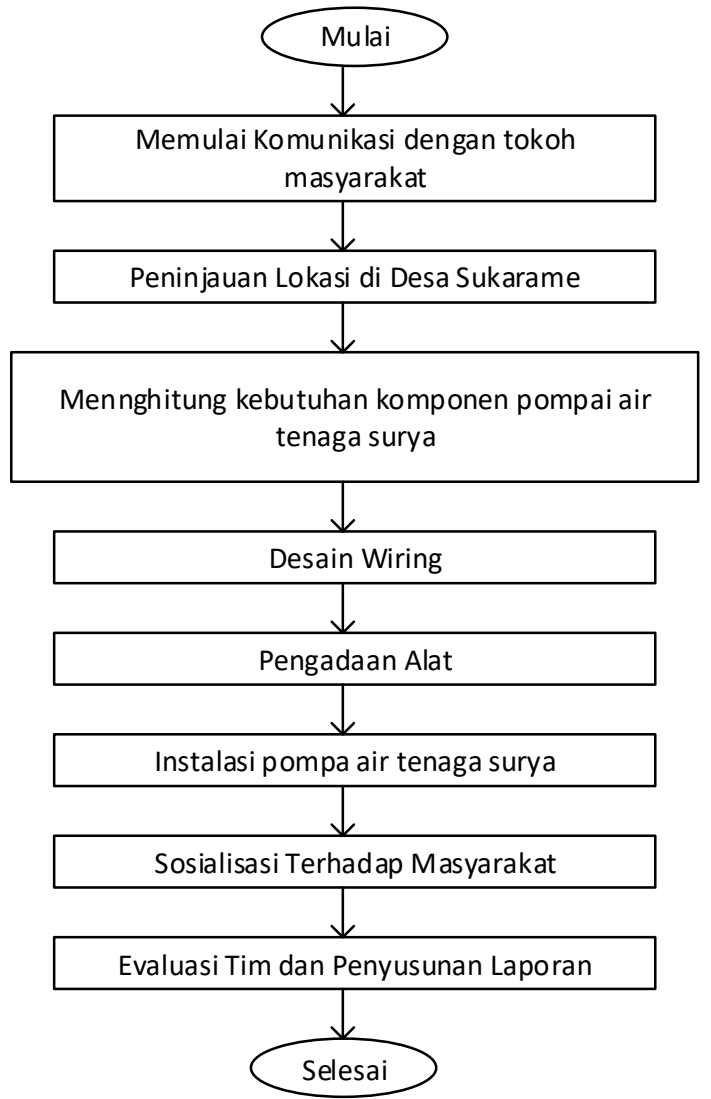

Gambar 2. Diagram Alir PKM 


\section{HASIL DAN PEMBAHASAN}

\subsection{Rancangan Sistem Pengambilan Air Bersih}

Sistem ini dimulai dengan merencanakan bangunan penampungan air bersih yang dihisap dari sumber air bersih (sumur tanah) menggunakan pompa air tenaga surya yang akan di simpan ke dalam tendon air kemudian akan didistribusikan ke masyarakat desa sukarame. Adapun debit air berasal dari sumur yang berkedalaman 15 meter. Sumur berada dilokasi yang lebih tinggi dari pesantren dan tidak ada sumber energi listrik dari PLN, seperti yang terlihat pada gambar 3.a.
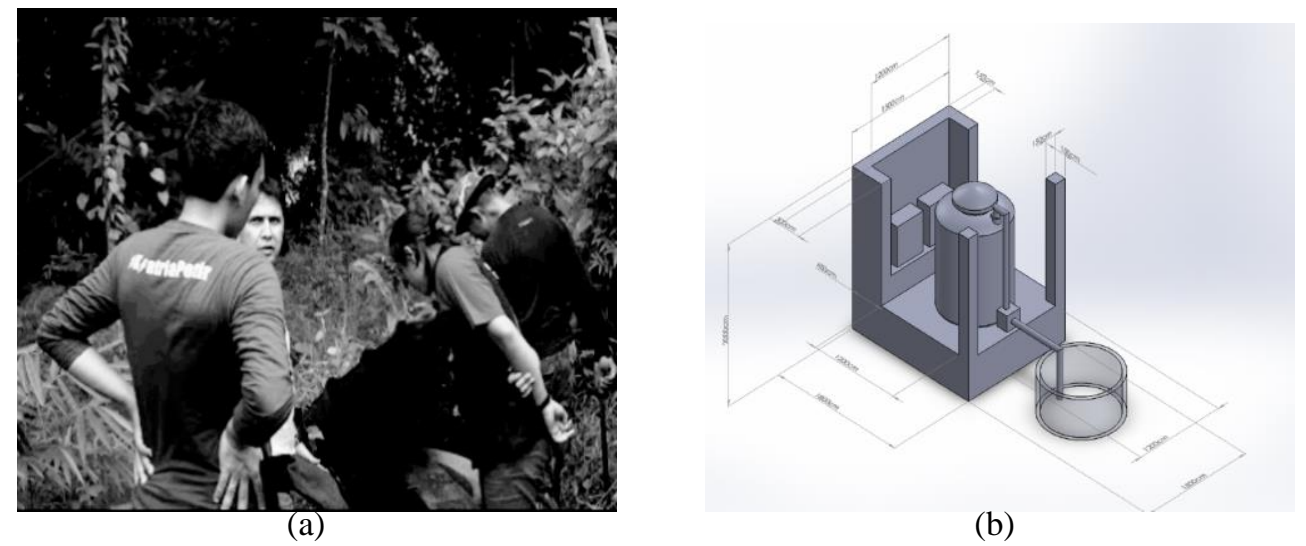

(b)

Gambar 2. Rancangan Pengambilan (Penyedotan) Air dari Sumber Mata air

Rancangan system pengambilan air nantinya akan didesain berdasarkan titik ssumber yang telah ditentukan. Gambara rancangan dapat dilihat pada gambar 3.b. Proses penyedotan dan penampungan air akan dibuat bak penampunag air yaitu menggunakan tandon berkapasitas $750 \mathrm{~L}$ (seperti terlihat pada gambar). Sedangkan untuk menarik air dari sumur menggunakan pompa air berkapasitasa 180 watt dengan sumber energi penggerak berasal dari panel surya yang berkapasitas $100 \mathrm{wp}$.

Pengisian tandon air dilakukan sebanyak $3 \mathrm{x}$ dalam sehari. Mengingat kapasitas dan kemampuan pompa air tenaga surya hanya bisa beroperasi maksimal 4 jam dalam sehari. Untuk pengisian penuh tandon diperkirakan akan memakan waktu sekitar 1 jam.

\subsection{Rancangan Perhitungan Kebutuhan Baterai dan Solar Panel}

Komponen pompa air tenaga surya yang digunakan untuk mendukung program kemitraan masyarakat ini adalah sebagai berikut :

1. Solar Panel

Solar panel mengkonversikan tenaga matahari menjadi listrik. Sel silikon (disebut juga solar cells) yang disinari matahari/ surya, membuat photon yang menghasilkan arus listrik. Sebuah solar cells menghasilkan kurang lebih tegangan 0.5 Volt. Jadi sebuah panel surya 12 Volt terdiri dari kurang lebih 36 sel (untuk menghasilkan 17 Volt tegangan maksimun). Pada program kemitraan masyrakat dengan judul "Perancangan Pemanfaatan Pompa Air Tenaga Surya Untuk Sumber Air Bersih Desa Sukarame" menggunakan 2 solar panel 100 wb yang artinya solar cell tersebut mempunyai 100 watt peak pada saat matahari terik, peak 1 hari diasumsikan 4 jam, sehingga 400 watt hour day adalah kapasitas maksimal dari solar cell 100 wp. 




Gambar 4. Solar Panel 100 wp

\section{Charge Control}

Cara kerja charger controller Pada waktu solar panel mendapatkan energy dari cahaya matahari di siang hari, rangkaian charger controller ini otomatis bekerja dan mengisi (charge) battery dan menjaga tegangan battery agar tetap stabil. Contoh. Bila kita menggunakan battery 12V, maka rangkaian ini akan menjaga agar tegangan charger 12 $10 \%$, tegangan charger yang di butuhkan antara 13,2-13,4 Volt. dan bila sudah mencapai tegangan tersebut, rangkaian ini otomatis akan menghentikan proses pengisian battery tersebut. Sebaliknya apabila tegangan battery turun / drop hingga 11 Volt, maka controller akan memutus tegangan sehingga battery tidak sampai habis. Secara keseluruhan Fungsi dari Controller ini yaitu dapat menjaga agar battery tidak kelebihan (over charger) dan kehabisan tegangan (under charger) dengan begitu maka umur dari battery bertambah lama. Pada program kemitraan masyarakat ini kami menggunakan pwm kontroler 12/24 V.

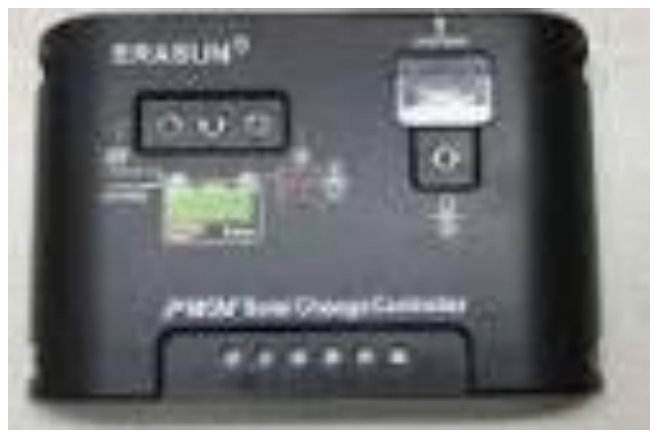

Gambar 5. PWM controller 12/24 V

3. Baterai

Tipe baterai yang digunakan adalah Valve Regulated Lead - Acid Battery, VA 12 - 100 (berkapasitas $100 \mathrm{Ah} 12 \mathrm{~V}$ ) pada port input dengan polaritas (+) dan (-). Baterai dapat digunakan apabila panas radiasi matahari tidak bisa diserap oleh solar panel ataupun penggunaan daya yang dihasilkan oleh solar panel tidak mencukupi untuk mengoperasikan pompa air. Untuk sistem kontrol pompa akan dilengkapi dengan conector, kabel dan box panel outdoor. Semua peralatan ini dapat dilihat pada gambar 6 . 


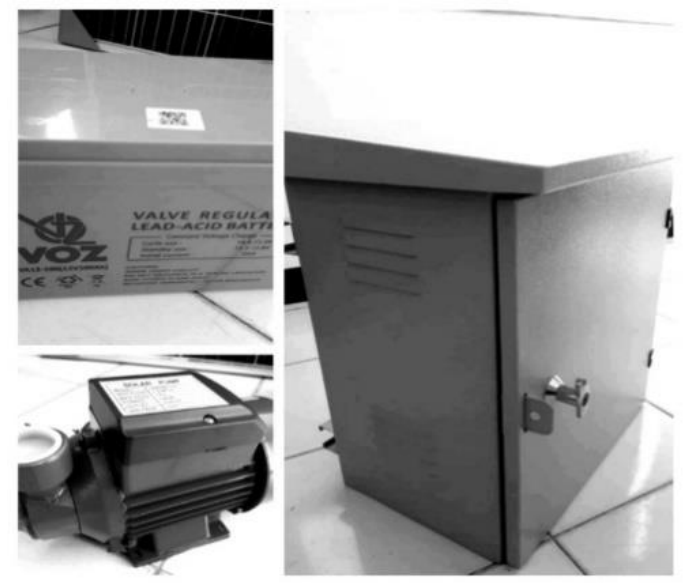

Gambar 6. Baterai dan Pompa Air

\section{Pompa Air DC}

Untuk jenis pompa air yang digunakan adalah tipe Solar Pump dengan daya 180 watt 12 $\mathrm{V}$, dengan kemampuan mendistribusikan air $1,5 \mathrm{~m}^{3} / \mathrm{jam}$ dan daya sedot dengan kedalaman sekitar 15 meter. Semua peralatan tersebut nanti akan dipasang dalam panel box untuk keamanan dan estetika pemasangan agar lebih rapi dan memudahkan dalam instalasinya. Semua peralatan tersebut dapat dilihat pada gambar 6.

\section{KESIMPULAN}

Berdasarkan rancangan dan kegiatan yang dilakukan maka dapat diperoleh kesimpulan sebagai berikut, sumber air untuk penyaluran berasal dari sumur yang berada $1 \mathrm{~km}$ dari rumah pendduk, untuk menyedot air dais umber air (sumur tanah) digunakan pompa air bertenaga surya yang akan dikumpulkan pada bak penampungan (toren) yang berkapasitas 750 L. Perancangan Pemanfaatan Pompa Air Tenaga Surya Untuk Sumber Air Bersih Desa Sukarame Kecamatan Sajira Kab. Lebak, Banten diharapkan mampu melayani kebutuhan akan air bersih masyarakat desa sukarame secara kontiniu selama musim kemarau berlangsung.

\section{SARAN}

Perancangan Pemanfaatan Pompa Air Tenaga Surya Untuk Sumber Air Bersih Desa Sukarame Kecamatan Sajira Kab. Lebak, Banten ini diharapkan dapat membantu masyarakat dalam mengatasi keterbatasan air bersih, sistem aka dapat berfungsi dengan maksimal jika sekiranya dalam pengoperasian dan pemeliharaan instalasi dilakukan dengan baik. Oleh karena itu masyarakat secara rutin memastikan sumber air tetap terjaga dengan baik, perlunya kesadaran masyarakat akan maintenance terhadap semua komponen pompa air tenaga surya, ke depan diharapkan controller panel surya dapat diupgrade menjadi control MPPT.

\section{UCAPAN TERIMA KASIH}

Penulis mengucapkan terima kasih kepada Institut Teknologi PLN Jakarta dan LPPM atas kesempatan kepada tim PKM dan dukungan baik moril maupun materiil serta pendanaan sehingga kegiatan PKM dapat terlaksana dengan baik. 


\section{DAFTAR PUSTAKA}

[1] Anastasya Feby Makawimbang, Lambertus Tanudjaja, Eveline M. Wuisan "Perencanaan Sistem Penyediaan Air Bersih Di Desa Soyowan Kecamatan Ratatotok Kabupaten Minahasa Tenggara,” Jurnal Sipil Statik Vol.5 No.1 Februari 2017 (31-40) ISSN: 2337-6732

[2] Fenny Nelwan, E. M. Wuisan, L. Tanudjaja "Perencanaan Jaringan Air Bersih Desa Kima Bajo Kecamatan Wori," Jurnal Sipil Statik Vol.1 No.10, September 2013 (678-684) ISSN: 2337-6732

[3] Alfredo Andrew, Tiny Mananoma, Jeffry S.F. Sumarauw, "Perencanaan Sistem Penyediaan Air Bersih Di Desa Rambunanan Amian Kecamatan Sonder Kabupaten Minahasa”, Jurnal Sipil Statik Vol.6 No.12 Desember 2018 (1055-1064) ISSN: 2337-6732.

[4] Manan, Saiful. 2009. Energi Matahari, Sumber Energi Alternatif Yang Effisien, Handal dan Ramah Lingkungan di Indonesia. Gema Teknologi

[5] Jaelani, A., Energi Baru Terbarukan Di Indonesia: Isyarat Ilmiah Al-Qur'an Dan Implementasinya Dalam Ekonomi Islam. University Library of Munich, Jerman. 2017.

[6] Nazmudin, Acep, "Alami Kekeringan Terparah Sejak 1997, Ribuan Warga Lebak Gelar Shalat Minta Hujan". Diakses online https://regional.kompas.com/read/2019/08/22/11113141/alami-kekeringan-terparah-sejak1997-ribuan-warga-lebak-gelar-shalat-minta.2019

[7] BPS, "Statistik Kesejahteraan Rakyat 2018”. Jakarta: Badan Pusat Statistik. 2018. 